\title{
Taze Peynirlerden İzole Edilen Escherichia coli Suşlarının Genotiplendirilmesi
}

\author{
Sadık Savaşan, Ergün Ömer Göksoy \\ Aydın Adnan Menderes Üniversitesi Veteriner Fakültesi, Besin Hij. ve Tek. AD, Aydın
}

Geliş Tarihi / Received: 12.10.2018, Kabul Tarihi / Accepted: 08.11.2018

\begin{abstract}
Özet: Bu araştırmada, Aydın ilinde üretilen taze peynirlerden izole edilen Escherichia coli suşlarının RAPD-PCR yöntemi ile genotiplendirilerek filogenetik yakınlıklarının ve ekolojik çeşitliliklerinin belirlenmesi amaçlanmıştır. Bu amaçla, Aydın ili ve çevresinde farklı mandıralarda üretilip, mandıra satış noktalarında, marketlerde ve semt pazarlarında satı̧̧a sunulan toplam 100 adet taze peynir numunesi koliform bakteri sayısı ile $E$. coli varlığı yönünden incelenmiştir. Her bir numuneden 250 gram olacak şekilde steril poşetler içerisinde soğuk zincir altında laboratuvara getirilmiştir. Taze peynir örneklerinin zenginleştirilmiş ve selektif besiyerlerine ekimlerini takiben izole edilen E.coli şüpheli bakterilerin biyokimyasal yöntemlerle identifikasyonu yapılmıştır. İdentifikasyon sonuçları PCR ile doğrulanmıştır. İzole edilen E.coli suşları RAPD-PCR yöntemi ile genotiplendirilmiştir. Sonuç olarak araştırmamızda 77 adet taze peynir örneğinde ortalama 4,83 log kob/g koliform bakteri saptanmış, koliform bakteri saptanan 77 adet taze peynir örneğinin 22 sinden 44 adet E.coli izolatı elde edilmiştir. Elde edilen 44 adet izolat PCR yöntemi ile de E.coli olarak doğrulanmıştır. $\mathrm{Bu}$ izolatların RAPD-PCR ile genotiplendirilmesi sonucu 22 farklı genotip belirlenmiş̧ir.
\end{abstract}

Anahtar Kelimeler: Taze peynir, E.coli, RAPD-PCR, genotiplendirme

\section{Genotypıng of Escherichia coli Strains Isolated From Fresh Cheese}

\begin{abstract}
The aim of this study was to evaluate phylogenetic and ecological diversity of E.coli strains isolated from raw cheese samples produced in Aydın province, by genotyping with RAPD-PCR technique. In this research, the fresh cheese materials produced at different dairy houses were obtained from dairy markets, local markets, district markets in and near Aydin province and they were investigated for colony forming unit of coliform bacteria and E.coli presence. 250 gr pieces of 100 fresh cheese samples that were obtained from different markets were taken in sterile bags and were brought to Adnan Menderes University. Veterinary Faculty, Food Hygiene and Technology Department laboratories in cold chain. After the enrichment and selective media processes, the isolated bacteria were identified by bio-chemical tests and PCR. After then, isolates were genotyped by using RAPD-PCR. As a result, in our study, coliform bacteria found in 77 fresh cheese materials at the average level of 4,83 log cfu/g., 44 E.coli isolates were identified in 22 of the 77 coliform contaminated samples.. The obtained 44 isolates were also verified as E.coli by PCR. 22 different genotypes were determined by genotyping of these isolates using RAPD-PCR.
\end{abstract}

Key Words: Fresh cheese, E.coli, RAPD-PCR, genotyping

\section{Giris}

Geleneksel bir süt ürünü olan peynir, farklı çeşitleri ile hemen hemen bütün tüketim gruplarına hitap etmekte ve insan beslenmesinde önemli bir yer tutmaktadır. Peynirin günlük beslenmemizde kolay sindirilebilme özelliğinin yanı sıra, yapısında üretimde kullanılan sütteki yağı, çözünmeyen tuzları, koloidal maddelerin tümüne yakın miktarını bulundurması ve süt serumundaki çözünen tuzlar, vitaminler, serum proteinleri ve diğer besin unsurlarının da bir ölçüde peynirin yapısına girmesinden dolayı önemli olarak kabul edilmektedir. Peynir ayrıca, yüksek kalitede protein, yağ, A ve B2 vitaminleri yönünden de oldukça zengindir [30].
Peynir her ne kadar güvenli bir gıda ürünü olarak bilinse de, pek çok semptomlarla ortaya çıkan gıda zehirlenmesi vakalarına neden olduğu olduğu bildirilmektedir. Peynir kaynaklı gıda zehirlenmelerine yol açan patojenler, kirli çevre veya infekte hayvan kaynaklı bulaşmış çiğ süt, süt işletmesi florasının ya da bu floranın çiğ süt kaynaklı kirliliği, üretim aşamasında çalışanlar kaynaklı olabilmektedir [18]. Ülkemizde peynirlerin fekal kontaminasyon ve patojen mikroorganizmalarla bulaşmasını, çiğ sütün toplam bakteri sayısı fazlalığına bağlı düşük kalitesi, sağım, taşıma, depolama aşamalarında ve işletmelerde, temizlik ve hijyen kurallarına yeterince önem verilmemesi, yeterli olgunlaştırma süresi dolmadan tüketime sunulması, uygunsuz koşullarda pazarlanması gibi faktörler olumsuz yönde 
etkilemekte ve bu durum tüketici sağ $\operatorname{llg}_{1}$ açısından önemli bir risk oluşturmaktadırlar [8,14,26,29].

Halk sağlığ1 için risk teşkil eden peynir kaynaklı zehirlenmelerin en önemli neden olarak ESCherichia coli gösterilmektedir. E. coli, Enterobacteriaceae familyasından, sporsuz gram negatif, uçları yuvarlak çomak şeklinde, çoğunlukla hareketli, asidorezistans özelliği olmayan, insan ve pek çok s1cakkanlı hayvanın doğal barsak florasında bulunan, optimum gelişme sicakl $\breve{g ̆}_{1} 37^{\circ} \mathrm{C}$, optimum gelișme pH's1 7,2 olan basil şekilli bir bakteridir [7,28]. E. coli, insan ve bazı memelilerin barsak florasında bulunması nedeniyle zararsiz olarak kabul edilse de, bazı tipleri gerek barsakta gerekse barsak dış1 ortamlarda insanlarda hastalıklara sebep olabilmektedir [15]. Gidalarda saptanması, saptanma miktarı, halk sağlı̆g 1 yönünden önem arz eden enteropatojenik ya da toksinejik E. coli bulunma ihtimali aç1sından, fekal kontaminasyonu gösterme açısından indikatör bir mikroorganizma olarak kabul edilir [22]. Çok sayıda patojen E. coli grubu bulunmakla birlikte, enteropatojenik E. coli (EPEC), enterotoksijenik E. coli (ETEC), enteroinvaziv E. coli (EIEC) ve enterohemorajik $E$. coli (EHEC) olmak üzere 4 grup önem arz etmektedir. Bu gruplar farklı E. coli serotiplerini içermektedir. Bir başka sınıflandırma şeklinde ise bazı E. coli serotipleri verotoksijenik (VTEC) grubu içinde toplanır. Bu gruplar dışında Meksika'da çocuklarda hafif geçen bir diareye neden olan diffuse adhering E. coli (DAEC), çeşitli ülkelerde bebek ve çocuklarda kronik diareye neden olan entero-aggregative E. coli (EAggEC), ender rastlanan facultatively enteropathogenic $E$. coli (FEEC) gruplar1 da mevcuttur. EAggEC serotipleri agregatif yapışma özellikleri ile diğer tüm $E$. coli serotiplerinden farkl1lık gösterir [13]. Patojenik $E$. coli alt grupları ile ilgili bazı özellikler ve semptomlar Tablo 1'de özetlenmiştir [11].

Tablo 1. Patojenik E. coli alt grupları ile ilgili bazı özellik ve semptomlar [11].

\begin{tabular}{lcccc}
\hline Özellikler/ & ETEC & EPEC & EHEC & EIEC \\
Semptomlar & LT/ST & - & Shiga veya Vero toksin & - \\
\hline Toksin & - & - & - & + \\
İnvaziv & - & + & + & - \\
İntimin & - & - & + & - \\
Enterohemolizin & Sulu & Sulu ve Kanlı & Sulu, Çok Kanlı & Mukoid, Kanlı \\
Dışk1 & Düşük & + & - & + \\
Ateş & - & - & - & + \\
Fekal lökosit & İnce Barsak & İnce Barsak & Kolon & Kolon,kismen ince barsak \\
İlgili Barsak & Çeşitli & O26, O111 ve diğerleri O157:H7, O26,O111 ve diğerleri & Çeşitli \\
Seroloji & Yüksek & Yüksek & Düşük & Yüksek \\
\hline IDb & &
\end{tabular}

$\mathrm{LT}=$ labil toksin (1sıya dirençsiz toksin), $\mathrm{ST}=$ stabil toksin (1sıya dirençli toksin) $\mathrm{I}_{\mathrm{d}}^{\mathrm{b}}=$ infektif doz.

$\mathrm{Bu}$ araștırmada, Aydın ilindeki çeșitli mandıra ve peynir işletmelerinde üretilen, market, pazar ve mandıra satış noktalarında tüketiciye sunulan taze peynirlerde $E$. coli varlığının araştırılması ve izole edilen suşlar arasındaki ekolojik çeşitliliğin saptanması amaçlanmıştır.

\section{Materyal ve Metot}

Çalışmada, Aydın ili ve çevresinde farklı mandıralarda üretilip, mandıra satış noktalarında, marketlerde ve semt pazarlarında satışa sunulan taze peynirler koliform bakteri sayıs ile E. coli varlığ1 yönünden incelendi. Bu amaçla çeşitli satış noktalarından toplam 100 taze peynir numunesi, her bir numuneden 250 gram olacak şekilde steril poșetler içerisinde soğuk zincir altında Adnan Menderes Üniversitesi, Veteriner Fakültesi Besin/ Gıda Hijyeni ve Teknolojisi Anabilim Dalı Mikrobiyoloji Laboratuvarına getirildi.

E. coli İzolasyon ve İdentifikasyonu: Toplanan peynir örneklerinden aseptik şartlarda alınan 10 'ar gram peynir numunesi stomacher torbalarına konulup, üzerine $90 \mathrm{ml}$ steril fizyolojik peptonlu su 
(Oxoid LP0005, Fluka 70179) ilave edilerek Stomacherde (Bag mixer, Interscience, France) 2 dakika boyunca homojenize edildi. Elde edilen homojenizattan seri dilüsyonlar hazırlanarak Violet Red Bile Agar'a (Oxoid CM0107) çift katlı dökme plak yöntemi ile inokulasyonlar yap 1 ld 1 ve takibinde $37^{\circ} \mathrm{C}$ ' de 24 saat inkübasyona birakıldı. İnkübasyon sonunda besiyerinde oluşan 1-2 mm çaplı koyu kırmızı koloniler sayılıp, sonuçlar log 10 tabanına göre koloni oluşturan birim/gram (kob/g) olarak değerlendirildi $[12,24]$. Koliform sayımından sonra VRB Agar' da üreyen kırmızı zonlu tipik kolonilerden 5 adet al1narak içerisinde Durhaim tüpü bulunan Lactose Broth'a (Oxoid CM0137) inokule edilip $44^{\circ} \mathrm{C}$ 'de 24-48 saat inkübasyona bırakıldı. İnkübasyon sonunda gaz ve bulanıklık oluşturan tüplerden Eosine Methylene Blue Agar (EMB) (Oxoid CM0069) ve MUG supplement (Oxoid BR0071) içeren Violet Red Bile Agar'a (Oxoid CM0107) öze ile ekim yapilarak $37^{\circ} \mathrm{C}$ 'de 24 saat bekletildi. EMB Agar'da metalik röfle ve MUG'lu VRB Agar'da uzun dalga boylu (366 nm) UV lambası ile floresan 1şıma veren kolonilere identifikasyon için İndol, Metil Red, Voges Proskauer ve Citrate (IMViC) testleri uygulandı [12,24]. Aynı peynir örneğinden izole edilen
E. coli suşları aynı numara ve farklı harflerle kodlandırıldi.

E. coli izolatlarının PCR ile identifikasyonu: DNA Ekstraksiyonu: PCR'da kullanılmak üzere $E$. coli izolatlarından total DNA ekstraksiyonu kaynatma yöntemi ile gerçekleştirildi. Bu amaçla şüpheli koloniler nutrient agara ekildi ve $37^{\circ} \mathrm{C}$ 'de $24-48$ saat inkübe edildi. Koloniler öze yardımı ile toplanarak, $500 \mu 1$ DNase-RNase free ependorf tüpünde deiyonize su ile süspanse edildi ve $100^{\circ} \mathrm{C}$ 'de 10 dk kaynatıld1. Daha sonra 10.000 rpm'de 5 dakika santrifüj edilerek üstteki sıv1 PCR'da hedef DNA olarak kullanılmak üzere saklandı [5].

PCR Amplifikasyonu: PCR identifikasyonunda Abd El-Razik ve ark [1]'nın kullandıkları protokol modifiye ve optimize edildi. PCR amplifikasyonu $50 \mu 1$ son hacim içinde gerçekleştirildi. Ekstrakte edilmiş 200 ng DNA, 2 mM MgCl${ }_{2}$, 1X PCR buffer, $1 \mu \mathrm{M}$ primer, $0,2 \mathrm{mM}$ dNTP ve $2 \mathrm{U}$ Taq polimeraz içeren PCR karışımı hazırlandı. Amplifikasyon koşulları olarak $95^{\circ} \mathrm{C}$ 'de $2 \mathrm{dk}$ ilk denatürasyon, 35 siklus olmak üzere $94^{\circ} \mathrm{C}$ 'de 45 sn denatürasyon, $57^{\circ} \mathrm{C}^{\prime}$ de $45 \mathrm{sn}$ bağlanma, $72^{\circ} \mathrm{C}$ 'de 45 sn uzama ve son siklustan sonra $72^{\circ} \mathrm{C}^{\prime} \mathrm{de} 10 \mathrm{dk}$ son uzama aşaması olacak şekilde ayarland1.

Tablo 2. E. coli izolatlarının tür tüzeyinde identifikasyonu için kullanılan oligonükleotid primerler.

\begin{tabular}{llll}
\hline Hedef bakteri & Oligonükleotid primer dizilimi & Bant büyüklüğü (bp) & Kaynak \\
\hline E. coli & F 5'-GCTTGACACTGAACATTGAG-3' & \multirow{2}{*}{662} & \multirow{2}{*}{ Abd El-Razik ve ark. [1] } \\
\hline
\end{tabular}

Amplikonlarin Görüntülenmesi: Amplifikasyon ürünleri etidium bromid $(2 \mu \mathrm{g} / \mathrm{ml})$ içeren $\%$ 1,5'lik agaroz jel elektroforezi sonrasında UV transilluminatör ile görüntülendi. Görüntüleme sonrasında 662 bp'lik bant görülmesi E.coli için pozitif olarak değerlendirildi.

İzolatların Genotiplendirilmesi: Tüm izolatlar ERIC (Enterobacterial Repetitive Intergenic Consensus)-2 (5'-AAG TAA GTG ACT GGG GTG AGC G-3') primeri kullanılarak RAPD-PCR profillerinin belirlenmesi sonrasinda gentiplendirildi. RAPD-PCR amplifikasyonu Versalovic ve ark [31] tarafindan bildirilen metodun modifiye edilmesiyle gerçekleştirildi. Bu aşamada deiyonize su, 1XPCR Buffer, 2,5 mM MgCl $2,200 \mu \mathrm{M}$ her bir dNTP, 2,5 U
Taq DNA polimeraz, 25 pmol primer ve $5 \mu 1$ template DNA içeren $25 \mu$ l'lik PCR karışımı oluşturuldu. $\mathrm{Bu}$ karışım $94^{\circ} \mathrm{C}^{\prime}$ de $5 \mathrm{dk}$ ön denatürasyonu takiben $94^{\circ} \mathrm{C}^{\prime} \mathrm{de} 1 \mathrm{dk}$ denatürasyon, $40^{\circ} \mathrm{C}$ 'de $1 \mathrm{dk}$ bağlanma, $72^{\circ} \mathrm{C}^{\prime} \mathrm{de} 3 \mathrm{dk}$ uzama olmak üzere 40 siklus ve $72^{\circ} \mathrm{C}$ 'de $7 \mathrm{dk}$ son uzama koşullarında amplifikasyon işlemine tabi tutuldu. Amplifikasyon ürünleri etidium bromid $(2 \mu \mathrm{g} / \mathrm{ml})$ içeren \% 1,5'luk agaroz jel elektroforezi sonrasinda UV transilluminatör ile görüntülendi. Oluşan RAPD paternlerinin dendrogramları UPGMA (Unweighted Pair Group Method with Arithmetic Averages) metodu ile Quantity One (BioRad) dendrogram ve görüntü analiz programı kullanılarak çizildi. 


\section{Bulgular}

İzolasyon ve İdentifikasyon bulguları: Peynir numuneleri koliform bakteri sayısı açısından değerlendirildiğinde 100 adet peynir numunesinin 77 adetinde $(\% 77)$ belirlenen dilüsyonlarda üreme saptandi. İncelenen peynir numunelerinin koliform bakteri sayısı sonuçları Tablo 3’te gösterilmiștir. İncelenen peynir numunelerinin 22 adetinde ( $\% 22) E$. coli varllğ 1 tespit edildi. Pozitif olan numunelerden 44 adet $E$. coli izolatı elde edildi (Aynı peynir örneğinden izole edilen $E$. coli suşları aynı numara ve farklı harflerle kodlanarak gösterildi).

Tablo 3. İncelenen peynir numunelerinin koliform bakteri sayısı sonuçları.

\begin{tabular}{|lccc}
\hline \multirow{2}{*}{ Koliform Bakteri Pozitif Numune Sayıs1 (77) } & \multicolumn{3}{c}{ Koliform Bakteri Sayıs $\left(\log _{10} \mathrm{kob} / \mathrm{g}\right)$} \\
\cline { 2 - 4 } & Minimum & Maksimum & Ortalama \\
\cline { 2 - 4 } & 2,47 & 6,54 & 4,83 \\
\hline
\end{tabular}

PCR Bulguları: Fenotipik olarak E. coli şüpheli izolatların PCR ile analizi sonrasında 44 adet izolatın 662 bp.'lik ürün verdiği görüldü ve identifi- kasyonu (Resim 1). Bu sonuçlara göre incelenen 44 adet izolat da $E$. coli olarak identifiye edildi.

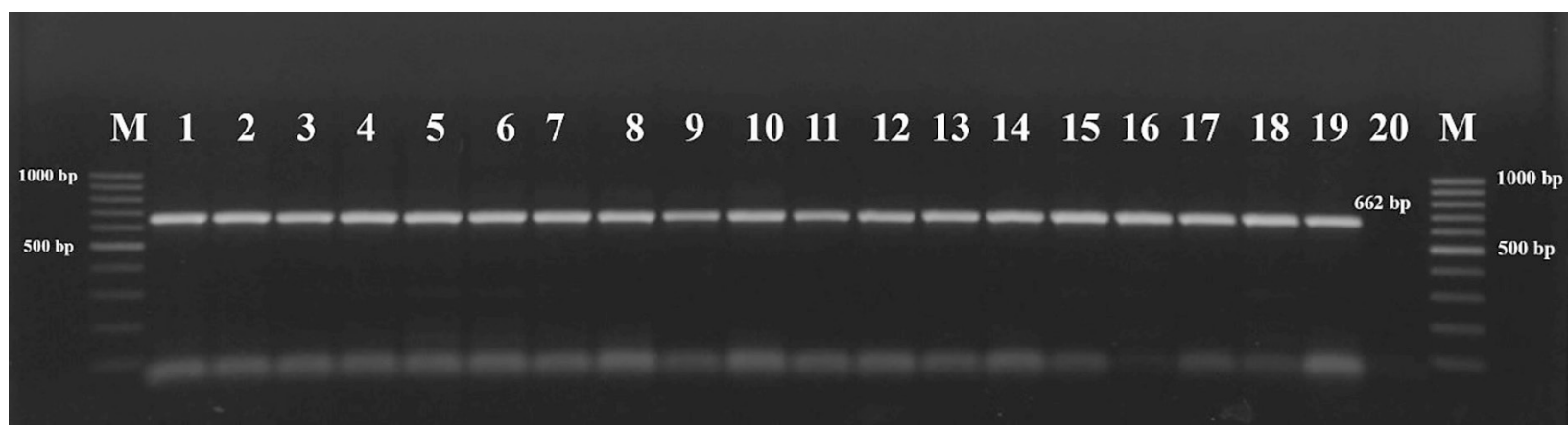

Resim 1. E. coli PCR sonuçlar1. M: marker (100 bp, Fermentas); 1-19: E. coli (662 bp), 20: negatif kontrol (Staphylococcus aureus).

Genotiplendirme ve Filogenetik Analiz: $E$. coli olarak identifiye edilen 44 adet izolatın genotiplendirmesi amaciyla ERIC-2 primeri kullanılarak gerçekleştirilen işlem sonucunda 22 farklı RAPD-
PCR profili tespit edildi (Resim 2). Onbir RAPDPCR profiline tek bir izolat düşerken, diğer 11 profil içinde \% 100 düzeyinde homoloji gösteren 2-6 izolat yer ald1.

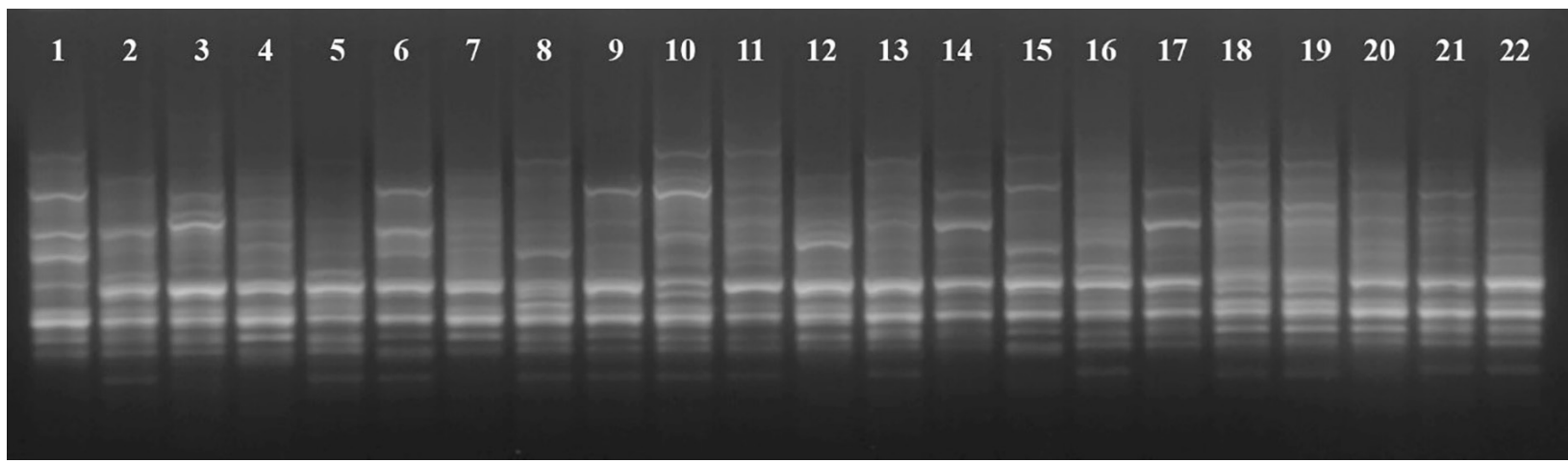

Resim 2. İncelenen E. coli izolatlarının RAPD profilleri. 
Dendrogramın \% 100 eșik değeri belirlenerek yapılan analizi sonucunda izolatların 11 adet tekli genotip ve 11 adet küme oluşturduğu belirlendi. Kümelerin 5 adetinin 2 izolat, 3 adetinin 3 izolat, 2 adetinin 4 izolat ve 1 adetinin de 6 izolattan oluştuğu saptand1 (Tablo 4).

RAPD-PCR profillerinin UPGMA (Unweighted Pair Group Method with Arithmetic Averages) ile yapılan filogenetik analizlerinin sonucu Şekil 1 'de gösterilmiştir. Buna göre, belirlenen 22 genotip arasinda 0,60-0,88 katsayı (\% 60-88) arasinda homoloji görüldü.

Çalışmada 7 genotipte $(1,2,7,12,20,21,22)$ sadece birer peynir örneğine ait suşlar yer aldı. Bununla birlikte 7 genotip içinde $(5,6,9,11,13,14$, 17) farklı peynir örneklerinden izole edilen suşlar aynı genotip içinde yer aldı (Tablo 5).

Diğer bir açıdan değerlendirildiğinde 6 peynir örneğinden farklı genotiplerde yer alan farklı suşlar (25.örnek 3.ve 5. genotip, 27.örnek 4. ve 5. genotip, 32. örnek 6. ve 8. genotip, 37. örnek 9. ve 10. genotip, 73. örnek 11., 15. ve 16. genotip, 84. örnek 18. ve 19. genotip) elde edildi (Tablo 5).
Tablo 4. RAPD-PCR sonucunda saptanan genotiplerde yer alan izolatlar ve sayıları.

\begin{tabular}{clr}
\hline Genotip Bakteri no & n \\
\hline 1 & $20 \mathrm{~B} 3 \mathrm{~A}$ & 1 \\
\hline 2 & $22 \mathrm{~B} 3 \mathrm{~A}$ & 1 \\
\hline 3 & $25 \mathrm{~B} 2 \mathrm{~B}$ & 1 \\
\hline 4 & $27 \mathrm{~B} 2 \mathrm{~B}, 27 \mathrm{~B} 2 \mathrm{~A}$ & 2 \\
\hline 5 & $25 \mathrm{~B} 3 \mathrm{~A}, 27 \mathrm{~B} 3 \mathrm{~A}$ & 2 \\
6 & $30 \mathrm{~B} 3 \mathrm{~B}, 32 \mathrm{~B} 3 \mathrm{~A}, 32 \mathrm{~B} 3 \mathrm{~B}$ & 3 \\
\hline 7 & $33 \mathrm{~B} 2 \mathrm{~A}$ & 1 \\
\hline 8 & $32 \mathrm{~B} 3 \mathrm{~A}$ & 1 \\
\hline 9 & $35 \mathrm{~B} 3 \mathrm{~A}, 35 \mathrm{~B} 3 \mathrm{~B}, 37 \mathrm{~B} 2 \mathrm{~B}, 37 \mathrm{~B} 3 \mathrm{~A}$ & 4 \\
\hline 10 & $37 \mathrm{~B} 3 \mathrm{~B}$ & 1 \\
\hline 11 & $44 \mathrm{~B} 3 \mathrm{~B}, 44 \mathrm{~B} 4 \mathrm{~B}, 44 \mathrm{~B} 3 \mathrm{~A}, 73-3 \mathrm{~A}$ & 4 \\
\hline 12 & $62 \mathrm{~B} 3 \mathrm{~A}$ & 1 \\
\hline 13 & $63 \mathrm{~B} 3,68 \mathrm{~B} 4$ & 2 \\
\hline 14 & $71-3 \mathrm{~A}, 71-4 \mathrm{~A}$, 69-4A & 3 \\
\hline 15 & $73-3 \mathrm{~B}$ & 1 \\
\hline 16 & $73-4 \mathrm{~A}$ & 1 \\
\hline 17 & $75-3 \mathrm{~B}, 75-4 \mathrm{~A}, 75-4 \mathrm{~B}, 78-3 \mathrm{~A}, 78-3 \mathrm{~B}, 78-4 \mathrm{~B}$ & 6 \\
\hline 18 & $84-3 \mathrm{~A}, 84-3 \mathrm{~B}$ & 2 \\
\hline 19 & $84-4 \mathrm{~A}$ & 1 \\
\hline 20 & $91-3 \mathrm{~A}$ & 1 \\
\hline 21 & $99-4 \mathrm{~A}, 99-4 \mathrm{~B}$ & 2 \\
\hline 22 & $100-3 \mathrm{~A}, 100-4 \mathrm{~A}, 100-4 \mathrm{~B}$ & 3 \\
\hline
\end{tabular}

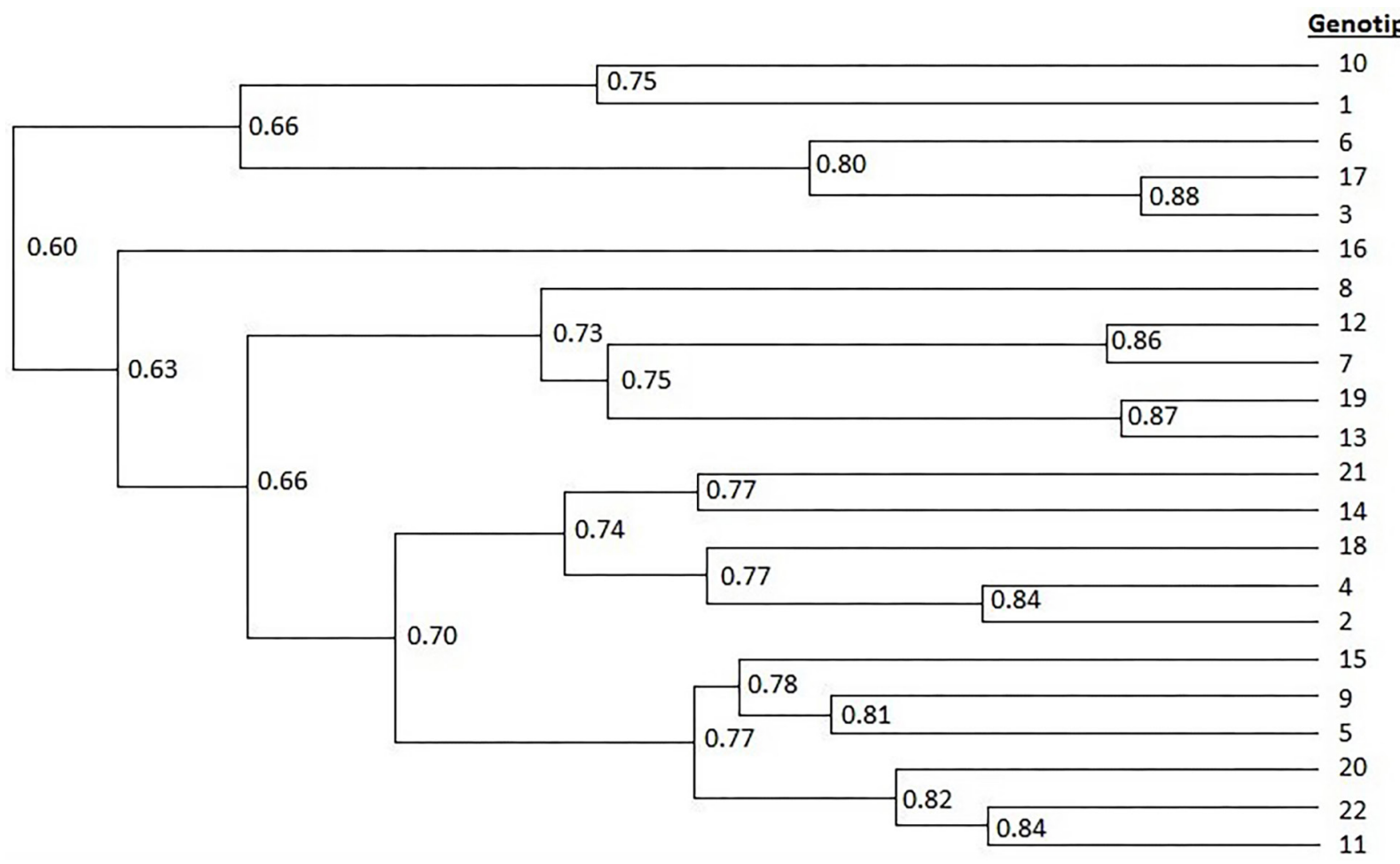

Şekil 1. İncelenen E. coli izolatlarının filogenetik yakınlık analizi sonucunda oluşturulan dendrogram (1 katsayı x 100 $=\%$ homoloji). 
Tablo 5. Belirlenen genotiplerin peynir örneklerine dağılımı.

\begin{tabular}{|c|c|c|c|c|c|c|c|c|c|c|c|c|c|c|c|c|c|c|c|c|c|c|}
\hline \multirow[b]{2}{*}{ GENOTIP* } & \multicolumn{22}{|c|}{ PEYNİR ÖRNEK (BAKTERİ No.) } \\
\hline & 20 & 22 & $* 25$ & $* 27$ & 30 & $* 32$ & 33 & 35 & $* 37$ & 44 & 62 & 63 & 68 & 69 & 71 & $* 73$ & 75 & 78 & $* 84$ & 91 & 99 & 100 \\
\hline$* * * 1$ & + & & & & & & & & & & & & & & & & & & & & & \\
\hline$* * * 2$ & & + & & & & & & & & & & & & & & & & & & & & \\
\hline 3 & & & + & & & & & & & & & & & & & & & & & & & \\
\hline 4 & & & & + & & & & & & & & & & & & & & & & & & \\
\hline$* * 5$ & & & + & + & & & & & & & & & & & & & & & & & & \\
\hline$* * 6$ & & & & & + & + & & & & & & & & & & & & & & & & \\
\hline$* * * 7$ & & & & & & & + & & & & & & & & & & & & & & & \\
\hline 8 & & & & & & + & & & & & & & & & & & & & & & & \\
\hline$* * 9$ & & & & & & & & + & + & & & & & & & & & & & & & \\
\hline 10 & & & & & & & & & + & & & & & & & & & & & & & \\
\hline$* * 11$ & & & & & & & & & & + & & & & & & + & & & & & & \\
\hline$* * * 12$ & & & & & & & & & & & + & & & & & & & & & & & \\
\hline$* * 13$ & & & & & & & & & & & & + & + & & & & & & & & & \\
\hline$* * 14$ & & & & & & & & & & & & & & + & + & & & & & & & \\
\hline 15 & & & & & & & & & & & & & & & & + & & & & & & \\
\hline 16 & & & & & & & & & & & & & & & & + & & & & & & \\
\hline$* * 17$ & & & & & & & & & & & & & & & & & + & + & & & & \\
\hline 18 & & & & & & & & & & & & & & & & & & & + & & & \\
\hline 19 & & & & & & & & & & & & & & & & & & & + & & & \\
\hline$* * * 20$ & & & & & & & & & & & & & & & & & & & & + & & \\
\hline$* * * 21$ & & & & & & & & & & & & & & & & & & & & & + & \\
\hline$* * * 22$ & & & & & & & & & & & & & & & & & & & & & & + \\
\hline
\end{tabular}

\section{Tartışma ve Sonuç}

İnsan ve hayvanların barsak florasında bulunan $E$. coli canlı için genellikle zararsız bir bakteri olarak kabul edilmektedir. Bazı patojenik türleri gıdaları kontamine edebilmekte veson yıllarda artış gösteren salgınlarda, her yıl yüzbinlerce insanın etkilendiği, yüzlercesinin de öldüğü saptanmıştır. Bu gıda zehirlenmelerinde kaynak insan veya hayvan dışkısıdır. Kontaminasyon yolu oldukça kompleks olabilmekte ve insanlar, hayvanlar, bitkiler ile tüm bunların ekosistemle etkileşimleri kaynak oluşturabilmektedir. Konakçı kaynak, sanitasyon ve hijyen düzeyleri, tarımsal sistemler, gida üretim yöntemleri, bakterinin epidemiyolojisi üzerine etkili unsurlar olarak karşımıza çıkmaktadırlar [9].
Amerika Birleşik Devletleri Gıda ve İlaç Dairesi (FDA), 2014 yılında çiğ sütten yapılmış 60 günlük peynirlerin mikrobiyolojik kalitesinin belirlenmesi amaçlı bir çalışma yapmıştır. Bu çalışmada 19 Şubat 2014 ile 3 Kasım 2015 tarihleri arasında 1606 adet peynir örneği toplanmıştır. Toplanan bu örneklerin 473 adetinin (\% 29) yerli üretim tarzında üretildiği, 1133 adetinin (\% 71) ise uluslararası peynir tiplerinden oluştuğu belirtilmiştir. Yerel peynir örnekleri üretim noktaları, depolar ve satış noktalarından, dış kaynaklı peynir örneklerinin ülkeye giriş noktası olan liman ve benzeri yerlerden, iç piyasaya sunulmadan önceki son kontrol noktalarından toplanmıştır. Bu çalışma sonucunda, 1606 adet örneğin 87 adetinde $E$. coli saptandığ 1 , çalışmanın bütünündeki kontaminasyon oranının ise \% 5.4'ü olduğu be- 
lirtilmiştir. E. coli saptanan örneklerden 18 adetinin yerel peynir, 69 adetinin dış kaynaklı peynir olduğu saptanmıştır. Toplam 1606 adet örneğin hiçbirinde E. coli $\mathrm{O} 157: \mathrm{H} 7$ bulunmadığ bildirilmiştir. Araştırmada 1606 örnekten 11 adetinde Shiga toksin üreten E. coli saptandığı, bu 11 adet örnekten 1 adetinde de patojenik serotip O111:H8 bulunduğu bildirilmiştir [10]. Madic ve ark. [20], çiğ sütten üretilen peynirlerde, Multiplex Real-Time PCR tekniğini kullanarak, 400 örnekte Shiga toksin üreten $E$. coli taramas1 yapmışlardır. Bu çalışmada 5 temel patojenik serotip olan O26:H11, O103:H2, O111:H8, O145:H28 ve O157:H7 serotiplerini araştırmışlar, 26 örnekte $(\%$ 6,5) bu serotiplerde Shiga Toksin üreten E. coli bulduklarını bildirmişlerdir. Quinto ve Cepeda [23] , yumuşak peynirlerde toksijenik E. coli insidensini araştırmak için yaptıkları çalışmada, 221 adet çi ̌̆ sütten yapılmış, 75 adet pastörize sütten yapılmış peynir örneklerini analiz ettiklerini, enterotoksijenik, verotoksijenik, nekrotoksijenik E. coli serotiplerini çalıştıklarını belirtmişlerdir. Pastörize sütten üretilen peynir örneklerinde toksijenik $E$. coli izole etmediklerini, çiğ sütten üretilen peynir örneklerinin 3 adetinde $(\% 1,35)$ toksijenik E. coli saptadıklarını bildirmişlerdir. Paneto ve ark. [21], Orta-Batı Brezilya'da satılan, çiğ sütten üretilmiş peynirlerde toksijenik $E$. coli varlığını araştırmak için planladıkları çalışmada, farklı marketlerden 50 adet örnek topladıklarını, analiz yöntemi olarak PCR tekniğini kullandıklarını bildirmişlerdir. Çalışma sonunda 48 adet (\% 96) örnekte E. coli saptadıklarını, bunlardan \% 6'sinin O125, \% 4'ünün O111, \% 2'sinin O55, $\%$ 2'sinin O119 serotiplerinde olduğunu belirtmişlerdir. Stephan ve ark. [25], İsviçre'de çiğ sütten üretilen peynirlerde STEC varlığını, serotiplerini saptamak amacıyla planladıkları araştırmada, ülke genelindeki üreticilerden Mart 2006-Aral1k 2007 tarihleri arasında 796 adet örnek topladıklarını bildirmişlerdir. Araştırmacılar, 2006 yılında toplanan 432 örnekten 16 adetinde $(\% 3,7), 2007$ y1lında toplanan 364 örnekten 23 adetinde (\% 6,3) STEC saptad1klarını belirtmişlerdir. Ahmed ve ark. [2], Mısır'da üretilen taze peynirlerde (Damietta ve Kareish) fekal koliform ve enteropatojenik $E$. coli varlığını araştırmak amacı ile 100 adet örnek topladıklarını, Damietta peynir örneklerinin \% 2'sinde E. coli düzeyinin $\geq 10^{3} \mathrm{kob} / \mathrm{g}$, Kareish peynir örneklerinin \% 84 'ünde $E$. coli düzeyinin $10-10^{3} \mathrm{kob} / \mathrm{g}$ olduğunu bildirmişlerdir. E. coli saptanan 46 adet Damietta ve
Kareish peynir örneklerinin 15 adetinin O125:B15, O25:K11, O128:B12, O126:B16 ve O111:B4 enteropatojenik E. coli (EPEC) ile kontamine olduğunu belirtmişlerdir. Ladan ve Reza [19], İran yerel taze peynirlerinde enteropatojenik E. coli (EPEC) kontaminasyon varlığını araştırmak amacıyla güney-batı İran, Kerman bölgesindeki satış noktalarından 77 adet örnek topladıklarını bildirmişlerdir. Topladıkları 77 adet örnekten 76 adetinde $(\% 98,70) E$. coli izole ettiklerini, bunlardan 15 adetinde de (\% 19,48) enteropatojenik E. coli (EPEC) saptadiklarını bildirmişlerdir. Tekinşen ve Özdemir [27], Van otlu peynirinde gida kaynaklı patojenlerin varlığ1nı araştırmışlar, bu amaçla olgunlaşmamış 50 adet peynir örneği topladıklarını belirtmişlerdir. Araştırma sonucunda, 31 adet (\% 62) örnekte $E$. coli izole ettiklerini, kontaminasyon düzeyinin 3,68 log kob/g olduğunu bildirmişlerdir. Keskin ve ark. [17], semt pazarlarında satılan beyaz peynirlerin mikrobiyolojik kalitesinin araştırılması amaçlı planladıklar1 çalışmada, İstanbul Üsküdar Belediyesine bağl 20 semt pazarındaki 50 beyaz peynir satıcısından, 2004 yılı Ocak-Mart aylarında peynir örnekleri aldıklarını, örneklerin \% 96'sında koliform bakteri, \% 86'sında E. coli izole ettiklerini bildirmişlerdir. Kaynar ve ark. [16], Ankara piyasasında tüketime sunulan beyaz peynirlerin hijyenik kalitelerinin belirlenmesi üzerine yaptıkları araştırmada, Ankara ili Ulus semtindeki marketlerden 30 adet peynir örneği aldıklarını, 21 adet örnekte koliform grubu bakteri izole ettiklerini, bu örneklerin 18 adetinde de $7,3 \times 10^{1}-2,4 \times 10^{2} \mathrm{kob} / \mathrm{g}$ düzeyinde fekal koliform ve $E$. coli saptadıklarını bildirmişlerdir. Doğan ve ark. [6], çeşitli gıdalarda koliform, fekal koliform, E. coli varlığının araştırılması amaçlı yaptıkları çalışmada, topladıkları 97 adet peynir numunesinin \% 78,4'ünde koliform bakteri, \% 75,3'ünde fekal koliform, \% 72,2'sinde E. coli izole ettiklerini bildirmişlerdir. Bingöl ve ark. [4], İstanbul'da satılan peynirlerde enterotoksin ve verotoksin varlığının araştırılması amacıyla yaptıkları çalışmada, topladikları 150 adet peynir numunesinden 55 adetinde $(\%$ 36,66) E. coli izole ettiklerini, 3 peynir örneğinde E. coli $\mathrm{O} 157$ saptadıklarını, hiçbir peynir örneğinde O157:H7 izole edilmediğini bildirmişlerdir. Arslan ve Özdemir [3], Türk ev yapımı beyaz peynirlerde E. coli O157'nin araştırılması amacıyla Bolu ilindeki açık halk pazarlarından, çiğ sütten ya da yetersiz pastörizasyon işlemi uygulanmış sütler- 
den üretilmiş, ev yapımı 245 adet beyaz peynir örneği topladıklarını belirtmişlerdir. Toplam 245 adet peynir örneğinin 21 adetinde $(\% 9,4) E$. coli izole ettiklerini bildirmişlerdir.

Gelişmiş olan ülkelerde taze peynirlerde $E$. coli varlığının, düzeylerinin saptanması amacı ile yapılan çalışmalarla ilgili incelenen makalelerdeki bulgulara göre, araștırmacılar taze peynirlerde \% 5-\% 6,5 düzeylerinde E. coli saptadıklarını, elde edilen bu sonuçların bir kısmının insanlarda oluşan salgınlarla ilişkilerinin belirlendiğini bildirmişlerdir $[10,20]$. Bu çalışmada taze peynir örneklerinde $\%$ 22 düzeyinde $E$. coli izole edilmiş olup, bu düzeyin gelişmiş olan ülkelerdeki saptanan düzeylere göre oldukça yüksek olduğu belirlendi. Bu sonuç, taze peynirlerde hijyen probleminin olduğunu ve elde edilen $E$. coli prevalansının halk sağlığı açısından önemli risk oluşturabileceğini göstermiş olup, bu konuda etkin çalışma ve eğitimlerin yapılmasının gerekliliğini ortaya koymaktadır.

Gelişmekte olan ülkelerde taze peynirlerde $E$. coli varlığının, düzeylerinin saptanması amacı ile yapılan çalışmalarla ilgili incelenen makalelerdeki bulgulara göre, araştırmacılar \% 46-\% 98 düzeylerinde $E$. coli saptadıklarını bildirmişlerdir $[2,19]$. Bu saptanan düzeyler çalışmamızda saptadığımız \% 22 E. coli düzeyinin oldukça üzerindedir. Bu sonuç, gelişmekte olan ülkelere göre peynir hijyeni ve teknolojisi açısından daha iyi bir noktada olduğumuzu göstermektedir.

Ülkemizde taze peynirlerde E. coli varlığının, düzeylerinin saptanması amacı ile yapılan çalışmalarla ilgili incelenen makalelerdeki bulgulara göre, Bolu ilinde yapılan çalışmada $E$. coli düzeyi \% 9,4 olarak bildirilmiş [3], diğer çalışmalarda ise \% 36 - \% 86 düzeylerinde $E$. coli saptandığ 1 bildirilmiştir $[4,17]$. İncelenen makalelerdeki çalışmaların yapıldığ coğrafi konumunun, ekonomik gelişmişliğinin saptanan $E$. coli düzeyleri üzerinde etkisinin olmadığ 1 gözlemlendi. Bu çalışmada saptanan \% 22 E. coli düzeyinin, ülkemizdeki sonuçlara göre düşük olduğu belirlenmiş ancak halk sağlığ açısından önemli riskler oluşturabilecek düzeyde olduğu saptanmıştır.

Bu çalışma ile ilk kez Aydın ilinde taze peynir örneklerinden izole edilen $E$. coli izolatlarının filogenetik analizleri yapıldı. İzole edilen $E$. coli izo- latlarının RAPD-PCR ile genotiplendirilmeleri ve filogenetik yakınlık analizleri sonucunda izolatların 22 farklı genotipe sahip olduğu ve bu genotiplerin $\%$ 60-88 arasında benzerliklere sahip oldukları belirlendi. Dendrogramın değerlendirilmesi ile izolatların 11 adet tekli genotip, 11 adet küme içerisinde yer aldığ 1 saptand1. Kümelerin 5 adetinin 2 izolat, 3 adetinin 3 izolat, 2 adetinin 4 izolat ve 1 adetinin de 6 izolattan oluştuğu görüldü. Halk sağlığı açısından önemli riskler oluşturan E. coli'nin peynirlere bulaşma yollarının ve aşamalarının çok çeşitliliği, bu çalışmada 22 farklı genotip saptanması ile ortaya konuldu. RAPD-PCR sonucunda \% 60-88 arasinda benzerlik gösteren 22 farklı genotip tespit edilmesi bölgedeki peynirlerde bulunan E. coli suşlarının ekolojik çeşitliliğini gösterdi. Bu çeşitlilik E. co$l i$ 'nin peynirlere bulaşma yollarının farklılığından kaynaklanabileceğini düşündürdü. Bu ekolojik çeşitlilik de halk sağlığı açısından önemli riskler oluşturan E. coli'nin peynirlere bulaşma yollarının ve aşamalarının daha net saptanması ve kritik kontrol noktalarının daha etkin şekilde belirlenmesinin gerekliliğini göstermektedir.

\section{Kaynaklar}

1. Abd El-Razik KA, Abderrahman KA, Ahmed YF, Gomaa AM, Eldebaky HA, (2010). Direct Identification of Major Pathogens of the Bubaline Subclinical Mastitis in Egypt using PCR. Journal of American Science , 6(10), 652-660.

2. Ahmed AH, Ahmed SH, Moustafa K, (1988). Occurence of Fecal Coliforms and Enteropathogenic Escherichia coli(EEC) in Egyptian Soft Cheese. Journal of Food Production, 51 (6), 442-444

3. Arslan S, Özdemir F, (2013). Investigation of Escherichia coli $\mathrm{O} 157$ in Turkish homemade White Cheese. Istanbul University Faculty of Science Journal of Biology, 72(1), 45-51.

4. Bingöl BE, Çetin Ö, Çolak H, Hampikyan H, (2012). Presence of enterotoxin and verotoxin in Turkish cheeses sold in İstanbul. Turkish Journal of Veterinary and Animal Sciences, 36(4), 424-432.

5. Ciftci A, Fındık A, Onuk EE, Savasan S, (2009). Detection of methicillin resistance and slime factor production of Staphylococcus aureus in bovine mastitis. Brazillian Journal of Microbiology, 40, 254-261.

6. Doğan BH, Çakır İ, Keven F, Coşansu S, Kıral N, Dağer İT, Gürsu G, Halkman KA, (2001). Çeşitli Gıdalarda Koliform, Fekal Koliform ve E. coli Varlığı. Gıda , 6(2), 83-90.

7. Dufty G, Whiting R, Sheridan J, (1999). The Effect of Competitive Microflora, $\mathrm{pH}$ and temperature on the growth kinetics of Escherichia coli O157:H7. Food Microbiology, 16, 299-307. 
8. Ergüllü E, (1980). Beyaz peynirlerin olgunlaşması sırasında mikrofloranın, özellikle gaz yapan bakterilerin değişimi üzerine araştırmalar. Ege Üniversitesi Ziraat Fakültesi Dergisi, s.21.

9. Food and Agriculture Organisation (FAO), (2011). Preventing E. coli in Food, 231.

10. Food and Drug Administration (FDA), (2016). FY 20142016 Microbiological Sampling Assigment. Summary Report: Raw Milk Cheese Aged 60 days. Office of Complience, Center for Foood Safety and Applied Nutrition.

11. Food and Drug Administration(FDA), (2016). Diarrheagenic Escherichia coli. Authors: Peter Feng, Stephen D. Weagent, Karen Jinneman. Bacteriological Analytical Manual, Chapter 4A.

12. Halkman KA, (2005). Merck Gıda Mikrobiyolojisi Uygulamaları. Başak Matbaacılık, Ankara, 141-182.

13. Halkman KA, (2013). G1da Mühendisliği II. Ders Notları, Ankara Üniversitesi, Mühendislik Fakültesi, Gıda Mühendisliği Bölümü, Ankara, 24-31.

14. Heperkan D, Sariyar L, Aytekin A, (1994). Peynirlerde Escherichia coli Gelişmesi ve Hijyenin Önemi. Animal, 9, 87-95.

15. Kaper JB, Natro JP, Mobely HLT, (2004). Pathogenic E. coli Natural. Review. Microbiology, 2, 123-140.

16. Kaynar Z, Kaynar P, Koçak C, (2005). Ankara Piyasasında Tüketime Sunulan Beyaz Peynirlerin Hijyenik Kalitelerinin Belirlenmesi Üzerine Bir Araştırma. Türk Hijyen Deneysel Biyoloji Dergisi, 62(1,2,3), 1-10.

17. Keskin Y, Özyaral O, Başkaya R, Susur M, (2006). Semt pazarlarında satılan beyaz peynirlerin mikrobiyolojik kalitesinin araştırılması. Türk Mikrobiyoloji Cemiyeti Dergisi, 36, 9-19.

18. Kousta M, Mataragos M, Skandomis P, Drosinos EH, (2010). Prevalance and sources of cheese contamination with pathogens at farm and processing levels. Food Control, 21(6), 808-815.

19. Ladan NM, Reza G, (2006). A study on enteropathogenic Escherichia coli isolated from domestic Iranian soft cheese. The Journal of Veterinarski Arhiv, 76, 531-536.
20. Madic J, Vingadassalon N, Garam P, Marault M, Sceutz F, Brugere H, Jamet E, Auvrey F, (2011). Detection of Shiga Toxin Producing Escherichia coli Serotypes O26:H11, O103:H2, O111:H8, O145:H28 and O157:H7 in Raw Milk Cheeses by Using Multiplex Real-Time PCR. Applied and Environmental Microbiology, 2035-2041.

21. Paneto BR, Hurrino SRP, Macedo C, Santo E, Marin JM, (2007). Occurence of toxigenic Escherichia coli in raw milk cheese in Brazil. Arquivo Brasileiro de Medicina Veterinaria e Zootecnia, 59(2).

22. Pamela L, Rinemann D, Kathryn H, (2008). The Effect of Milking Management on Microbial Quality Presented at XII. Curso. Novas Enfoques Na producose reproduced de Bovinos, Uberlandia, Brazil.

23. Quinto EJ, Cepeda A, (1997). Incidence of toxigenic Escherichia coli in soft cheese made with raw or pasteurized milk. Letters in Applied Microbiology, 24, 291-295.

24. Roberts D, Greenwood M, (2003). Practical Food Microbiology. 3rd edition, Blackwell Publishing, 150-170.

25. Stephan R, Schumacher S, Corti S, Krause G, Danuser J, Beutin L, (2008). Prevalence and Characteristics of Shiga Toxin Producing Escherichia coli in Swiss Raw Milk Cheeses Collected AT Producer Level. Journal of Dairy Science, 91(7), 2561-2565.

26. Tan S, Ertürk YE, (2002). Peynir. TEAE Bakış Dergisi, 1(11), 1-4.

27. Tekinşen KK, Özdemir Z, (2006). Prevalence of the foodborne pathogens in Turkish Van otlu (herb) cheese. Food Control, 17(9), 707-711.

28. Töreci K, (2002). Escherichia türleri. İnfeksiyon Hastalıkları ve Mikrobiyolojisi, 2.bask1, 1564-1574.

29. Tunail N, (1999). Mikrobiyel enfeksiyonlar ve intoksikasyonlar. In: Akçelik M, Aydar LY, Ayhan K, Çakır İ, Doğan HB. Gıda Mikrobiyolojisi ve Uygulamaları. Armoni Matbaacılık Ltd. Şti., Ankara, 59-90.

30. Üçüncü M, (2013). Süt ve Mamülleri Teknolojsi. Meta Basım Matbaacılık, İzmir.

31. Versalovic J, Koeuth T, Lupski JR, (1991). Distribution of repetitive DNA sequences to fingerprinting of bacterial genomes. Nucleic Acids Research, 19(24), 6823-6831. 